KEYWORDS

Globalization

Syndicalism

Economic development

International trade

Employment

Income distribution

Developing countries

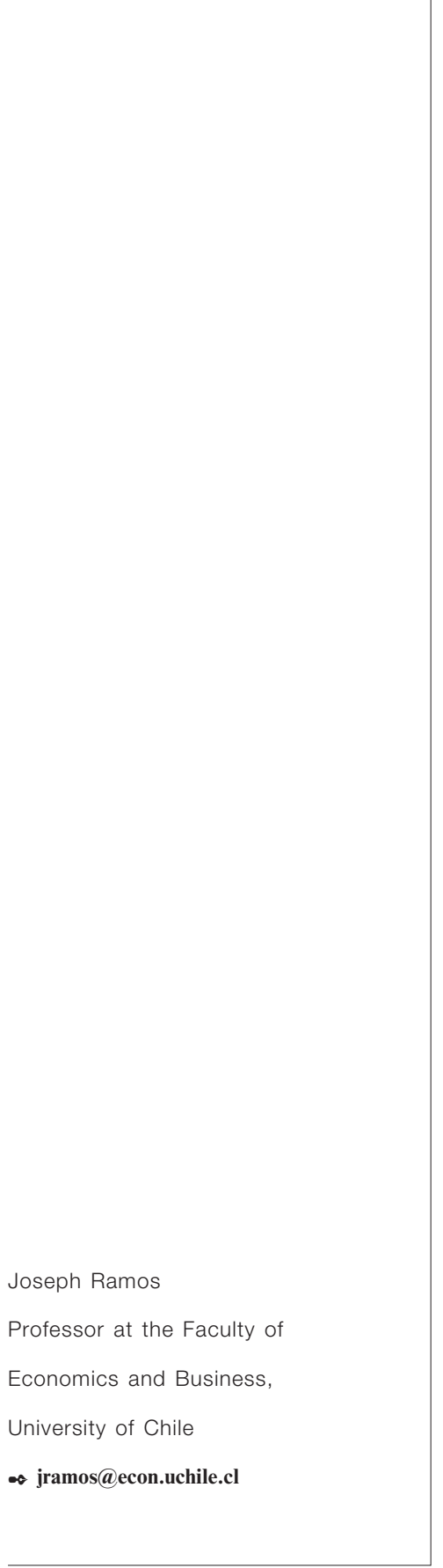

CEPAL REVIEW 100 APRIL 2010

\section{Trade unions in the "South" in the era of globalization}

\author{
Joseph Ramos
}

$\mathrm{T}$

his article examines the effects of globalization on the trade union movement in developing countries (the "South"). It concludes, first, that globalization has been asymmetrical: much further-reaching for trade in goods than for capital flows, weak for technology transfer and very limited in migratory flows. Second, it examines the role and economic repercussions of labour unions. It finds that, contrary to the orthodox view, these have little negative impact on employment but do significantly reduce wage inequalities. In view of the shift in the South since the 1980s away from development strategies based on import substitution aimed at domestic markets and towards export-oriented strategies, the final section proposes new tasks and priorities for unions that are more consistent with this strategic reorientation, both at the national and international levels as well as within firms. 


\section{I}

\section{Introduction}

Trade unionism, as traditionally understood, probably peaked as a major force in the economy shortly after the Second World War. Unions then accounted for a large proportion of the workforce, had considerable negotiating power and were highly influential in national politics. For different reasons, their power began to diminish. Their influence may be under even greater threat in today's world, characterized by "globalization" in which economic decisionmaking is increasingly shifting from the national to the international sphere.

The aim of this article is to examine the implications of globalization for trade unions, and most especially for those in the countries of the Third World (the "South"). What threats are looming? What opportunities, if any, are emerging? What adjustments will unions have to make in the way they operate if they wish to continue being important actors in their own countries and internationally?

This article will not scrutinize the merits or otherwise of globalization but will set out from the premise that this is, broadly speaking, here to stay and if anything is likely to advance further. What will be considered, rather, is how the trade union movement can modify those trends in globalization that most seem to threaten its interests, or accelerate those that are potentially most favourable to it. The view taken is that trade unionism is a vital institution in society, whose future depends to a great degree on its continuing to be able to successfully represent workers' interests, but in a way that is attuned to the future needs of our society.

Following this Introduction, the second section will examine globalization and the debates surrounding it, and will highlight five key facts characterizing it. The third section will analyse the traditional roles of trade unions and the way these have been evolving, the perception of globalization among workers, and international trends (generally declining) in unionization and their effects. The fourth and last section will consider the impact of globalization on unions in developing countries (the "South"), especially Latin America, and will try to elucidate the implications of globalization for the trade union movement, with a view to its continuing to be an influential agent in society.

\section{II}

\section{The trend towards globalization}

\section{What is meant by globalization?}

Globalization has been succinctly defined as "competing with everyone from everywhere for everything". More formally, globalization can be described as the process whereby a country's production comes to depends less on its own economic policies and local conditions as its production system becomes increasingly open to, and dependent upon, factors external to it: capital flows, labour (migration) and technology which, along with rising trade in goods and services, determine what is produced and consumed and what is imported and exported.

\section{The debate ${ }^{1}$}

The main debate about the tendency towards globalization turns on whether it is a good or bad thing. One criticism is that it forces countries to "compete downward", i.e., that the need to compete internationally obliges countries to lower their national standards to the lowest standards

\footnotetext{
1 A good introduction to the globalization debate can be found in Micklethwait and Wooldridge (2000). Gray (1998) and Stiglitz (2003) provide some of the sharpest, although still measured, criticism. Bhagwati (2004) offers a staunch defence of globalization.
} 
prevailing in the world. The result is competition to cut wages (or at least not raise them), reduce labour and environmental standards and tax firms less. This economic criticism is accompanied by a cultural one to the effect that globalization threatens to put an end to each nation's idiosyncrasies, resulting in the predominant culture, that of the United States, prevailing over local cultures. This is what is called the "McDonaldization" of the world.

The defenders of globalization, on the other hand, say that it is a process which benefits all countries, not just developed ones but also, and particularly, those in the developing world, since it will help to accelerate their growth. In defence of their viewpoint, they argue that multinationals usually pay better wages than local firms, apply higher environmental and employment standards than are required by national laws, comply more punctiliously with their obligations in these matters and evade taxes less often than local firms. The free trade that globalization has brought with it, meanwhile, has given local consumers access to cheaper, better-quality products. Regarding the cultural aspect, they insist that local culture still dominates the media (television programmes), while foreign culture is secondary and is usually a source of diversity that has an enriching rather than a homogenizing effect.

The debate is too heated and involved to be settled in this article. We would venture two general opinions, however. First, while there may be attractions to investing in the South to take advantage of its lower labour and environmental standards, this situation is likely to be temporary. Sooner or later, globalization itself will tend to raise standards in the South, as the developed countries will increasingly make this a condition for keeping their markets open to exports from the South. Consequently, the countries of Latin America will be required to comply with environmental and labour legislation and not treat it as a dead letter, as sometimes happens, by turning a blind eye to violations.

Secondly, both sides of the debate exaggerate greatly. Globalization may not be a positive sum game, as its proponents claim, but neither is it a negative sum game, as some of its detractors suggest. In the debate about the North American Free Trade Agreement between Mexico and the United States, for example, detractors argued that the inhabitants of both countries would lose out. The fear of many in the United States, like the presidential candidate Ross Perrot, was that United States firms would set up in Mexico to take advantage of its much cheaper labour. Consequently, the Agreement would hurt the United States and benefit Mexico. Meanwhile, many Mexicans had the opposite fear: how were Mexican firms going to survive if they had to compete with imports produced by far more productive United States firms? Consequently, the Agreement would benefit the United States at the expense of Mexico. Clearly, the two arguments are contradictory and cannot be generally true. ${ }^{2}$

Defenders of globalization who present it almost as a panacea for emerging countries also overstate their case. However important market opening may be for the economic development of the South, the crucial thing is what is done to raise their dismal productivity. This does not come from outside but essentially depends on an internal effort.

Let it be repeated that, while there can be no question of resolving this debate in the present article, it is important to bear it in mind when analysing the key issues of globalization that we shall highlight, as it contextualizes and partially determines the possible implications.

\section{Five key facts}

The huge disparities in income and productivity between the developed countries of the "North" and the developing countries of the "South" are notoriously due to the fact that the North has an abundance of capital and modern technology and a scarcity of labour. The "South", meanwhile, has the opposite characteristics: capital is in short supply and outdated technologies prevail, while labour is relatively abundant. In theory, closing these divides means taking capital and technology from the North to the South and moving labour from the South to the North. This can be done directly by flows of capital, labour and technology, and also indirectly through trade in goods, with the South exporting its surplus labour in the form of highly labour-intensive goods.

\footnotetext{
2 The truth of the matter seems to be that United States firms whose productivity advantage outweighs the pay differential with Mexico export to the latter, while Mexican firms whose productivity disadvantage is not as great as the pay differential export to the United States. Thus, more productive firms and activities in each country will expand and less productive ones decline. While the net effect may be positive, there will be gainers and losers in both countries. Furthermore, the two sides will not necessarily gain alike, whence the need for skilful negotiations and a national economic policy that is in keeping with development needs.
} 
It is true that globalization tends in this direction. To anticipate the conclusions that will follow, however advanced globalization may be, current flows are much less than are needed to rapidly close these income and productivity gaps. Furthermore, we shall observe a large asymmetry between the different flows, as some are very substantial (trade in goods), some are scant (migration and technology flows) and others are somewhere in the middle (capital flows).

The first fact is the growing importance of international trade, i.e., flows of goods between countries. Figure 1 shows the growth in the world's export volumes and gross domestic product (GDP) since 1870: first from 1870 to 1950 , then from 1950 to the present. From 1870 to 1950 , exports and GDP grew at similar rates, with both more or less quintupling over the period. However, in the second period, from 1950 to the present, exports have exploded. They have increased 22-fold, compared to a large (7.5-fold) but lesser increase in GDP. Thus, taking the entire period from 1870 to the present, we find that while global GDP has multiplied 36-fold in those 138 years, i.e., at a rate of about $2.6 \%$ a year, exports have grown 130 -fold, i.e., at a rate of some $3.6 \%$ a year.
Consequently, exports as a share of GDP have more than quadrupled from 5\% of GDP in 1870 to $23 \%$ in 2008 (see figure 2). Although this represents extraordinary growth, the fact remains that three quarters of what is produced each year continues to be consumed domestically, and the reason for this is that much of this annual production consists of goods that are difficult or impossible to export. In practice, the great bulk of spending on health, education, government, commerce, services and construction, typically making up $60 \%$ of each country's GDP, is not tradable internationally.

This increase in international trade has been due to a whole range of factors. Among the most important are large reductions in transport costs, both between 1870 and 1950 and from 1950 to the present day. Second, there is the process of economic integration in Europe since the Second World War, culminating in its common market and single currency. Third, and once again since 1950, there have been the different rounds of multilateral tariff cuts promoted by the General Agreement on Tariffs and Trade (GATT), following large tariff increases in the period between the two world wars. Lastly, there

FIGURE 1

World export and GDP growth, 1870 to present

(Index: 1950=100)

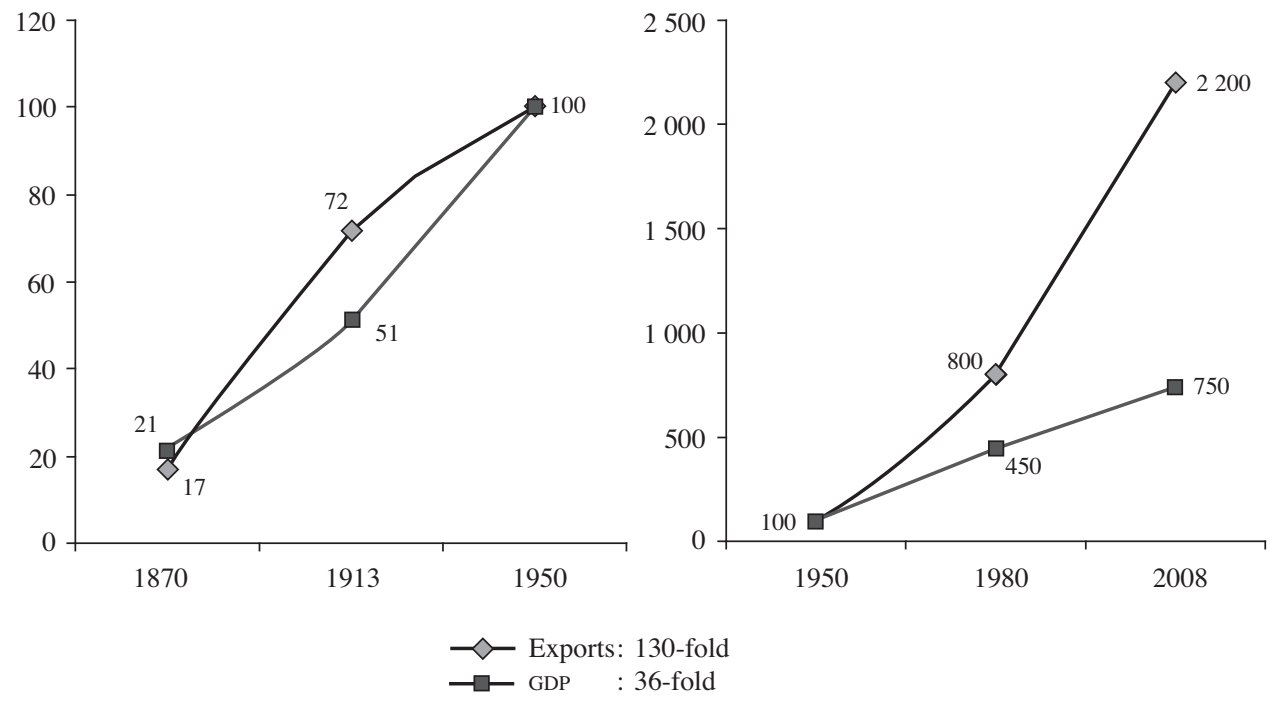

Source: Angus Maddison, The World Economy: A Millennial Perspective, Paris, Organisation for Economic Co-operation and Development (OECD), 2001, and author's information from 1998 onward.

N.B.: The 1870-1950 and 1950-2008 periods are separated for presentation purposes. 
FIGURE 2

\section{Exports as a percentage of GDP, 1870 to present}

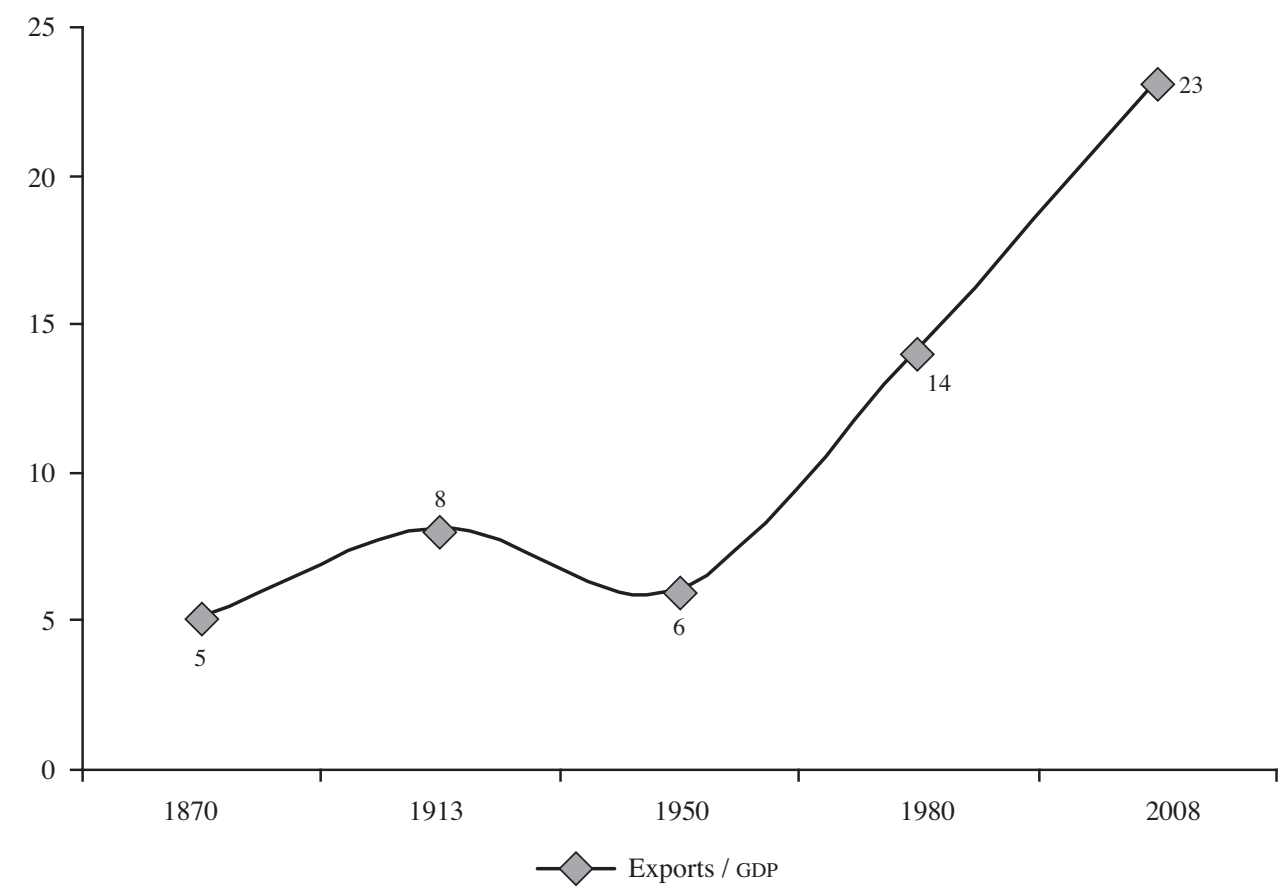

Source: Angus Maddison, The World Economy: A Millennial Perspective, Paris, Organisation for Economic Co-operation and Development (OECD), 2001, and author's information from 1998 onward.

N.B.: The 1870-1950 and 1950-2008 periods are separated for presentation purposes.

are the numerous bilateral and subregional economic integration agreements concluded in the late twentieth and early twenty-first centuries.

In Latin America, this increase in trade has been partly driven by the trade liberalization policies brought in during the 1980s following the external debt crisis. This was a time when the region's countries made a strategic shift from an industrialization strategy based on high tariff protection and import substitution to a low-tariff exporting model. The average tariff in the region dropped from about $30 \%$ in the early 1980 s to some $10 \%$ now (see table 1 ). Innumerable bilateral and subregional trade agreements have also been signed or given greater depth. As a result, the share of exports in Latin American economies has risen from some $13 \%$ of GDP in 1980 to about $25 \%$ now.

Nonetheless, most international trade is not between developed countries, which export industrial products, and developing ones, which export raw materials, but consists of different industrial exports from one country of the North to another. Thus, 77\% of exports from the North go to other countries in the North (see table 2), with just $23 \%$ going to the South.
This perhaps unexpected finding is due to the fact that more exports go to markets with greater purchasing power. Again, many of the "comparative advantages" of the North reside not so much in capital-intensive industries as in knowledge-intensive ones; and there can be no doubt that most knowledge is currently generated in the North. It is for these two reasons that the bulk of exports from the North go to other countries of the North.

Precisely because trade in goods leads each country to specialize in whatever it is relatively efficient at, it also allows countries with an abundance of raw materials and labour, such as those of the South, to export some of this abundance to the markets of the North in the form of raw material- and labourintensive goods. Nonetheless, since much raw material production is capital-intensive (mining and energy, for example), in net terms our exports are not particularly labour-intensive. Thus it is that our exports are a very imperfect substitute for the movement of factors, i.e., for the migration of labour from the South, where it is abundant, to the North, where it is scarce, and for the movement of capital in the other direction, 
TABLE 1

Tariff reductions in Latin America, 1980-2006

(Percentages)

\begin{tabular}{lccc}
\hline Country & Mid-1980s & 2006 & Reduction (points) \\
\hline Argentina & 28 & 12 & -16 \\
Brazil & 52 & 9 & -43 \\
Chile & 20 & 6 & -14 \\
Colombia & 28 & 12 & -16 \\
Ecuador & 28 & 9 & -19 \\
Mexico & 12 & 11 & -1 \\
Peru & 40 & 7 & -33 \\
Venezuela (Bol. Rep. of) & 33 & 15 & -18 \\
Latin America & 30 & 10 & -20 \\
\hline
\end{tabular}

Source: World Trade Organization (WTO), World Tariff Profiles 2008, Geneva, 2008.

TABLE 2

International trade flows

(Trillions of dollars)

\begin{tabular}{|c|c|c|c|c|}
\hline Trade flows & Global imports & \multicolumn{2}{|c|}{$\begin{array}{l}\text { Developed-country } \\
\text { imports }\end{array}$} & $\begin{array}{c}\text { Developing-country imports } \\
\text { (Latin America) }\end{array}$ \\
\hline Global exports & 13.9 & 9.8 & & $\begin{array}{l}4.1 \\
(0.75)\end{array}$ \\
\hline Developed-country exports & $\begin{array}{r}9.8 \\
71 \%\end{array}$ & 7.5 & $77 \%$ & $\begin{array}{l}2.3 \\
(0.54)\end{array}$ \\
\hline Developing-country exports & $\begin{array}{r}4.1 \\
29 \%\end{array}$ & 2.3 & $56 \%$ & $\begin{array}{l}1.8 \\
(0.21)\end{array}$ \\
\hline
\end{tabular}

Source: World Bank, World Development Report 2009, Washington, D.C., 2009.

from the North, where it is abundant, to the South, where it is scarce.

Without a doubt, the sheer scale of goods and services flows makes exports and trade liberalization the most salient feature of globalization.

The second fact, next after trade in importance, is the flow of capital between countries and, more specifically, foreign direct investment (FDI). Table 3 shows that some US\$ 1.8 trillion of capital is invested outside its country of origin each year in the form of FDI. As might be expected, $90 \%$ of this investment originates in the developed countries. Perhaps surprisingly, though, the bulk of this investment (two thirds) goes to other developed countries in the North, where capital is also abundant, and not to capital-scarce developing countries, which receive a third of this investment. The reason for this is that
FDI is not only deployed to extract natural resources and then process them (which is what FDI is typically for in the South), but is also used, and on an even larger scale, to take advantage of the proximity of large markets, most of them in the North. Thus, the purpose of FDI in the South is usually to extract natural resources, copper for example, and then turn them into industrial products in the North such as electrical cables. Conversely, the usual reason for siting FDI in the North is for a firm to position itself close to large markets, examples being Japanese car plants in the United States and United States car plants in Europe. This explains why most FDI is between developed countries.

It should be noted, however, that FDI in developing countries has been growing rapidly, from US\$ 6 billion in Latin America in 1980 to 20 times 
TABLE 3

Foreign direct investment (FDI) worldwide, 2007

(Trillions of dollars)

\begin{tabular}{lccc}
\hline \multicolumn{1}{c}{ FDI } & World receives & Developed countries receive & $\begin{array}{c}\text { Developing countries receive } \\
\text { (Latin America) }\end{array}$ \\
\hline World invests & 1.8 & 1.2 & 0.6 \\
& & & $(0.125)$ \\
Developed countries invest & 1.7 & 0.115 & 0.55 \\
Developing countries invest & 0.1 & 0.05 & 0.05 \\
\hline
\end{tabular}

Source: World Bank, World Development Report 2009, Washington, D.C., 2009.

that amount now (see table 4). This is all the more important considering that FDI is likely to bring with it more and better technology than local investment, so that foreign investment has become an important factor in the development of the South. It must be recognized, however, that this still represents less than a fifth of the investment carried out each year in Latin America and an even lower percentage (a mere 3.7\%) of the region's GDP, which shows that international factor mobility falls considerably short of what the textbooks predict.

The fact is that $90 \%$ of all investment in the world still has a strongly "insular" tendency, i.e., is carried out within the home country. Although there are probably more investment opportunities in the emerging economies of the South than in the mature markets of the North, the great majority of firms still prefer to invest in their home markets. There are all sorts of reasons for this "non-globalizing" tendency: businesses have a better understanding of opportunities in their own markets, these opportunities are more circumscribed by local legislation, or owners are not willing to capitalize enough to internationalize, as this would dilute their control over the firm.

One consequence of this "under-globalization" of capital from the North, neglecting important investment opportunities in the South, is to lower the potential returns on capital in the North. Those who come off worst, however, are the abundant workers of the South, who, in the absence of strong capital flows from the North, are forced to take employment in local firms with their outdated technology and low capital intensity, and the low wages and productivity that result.

This point is not invalidated by the argument, put forward by many critics of globalization and FDI, that a great many firms come to the South to take advantage of low wages. While this may well be

TABLE 4

\section{Foreign direct investment (FDI) in Latin America, 1980-2007 \\ (Millions of dollars)}

\begin{tabular}{lccc}
\hline & 1980 & 2004 & 2007 \\
\hline FDI in Latin America & 5700 & 60000 & 126300 \\
FDI/GDP & $0.4 \%$ & $3.0 \%$ & $3.7 \%$ \\
FDI/total investment & $2.0 \%$ & $15.0 \%$ & $17.8 \%$ \\
\hline
\end{tabular}

Source: United Nations Conference on Trade and Development (UNCTAD), World Investment Report 2008 (UNCTAD/WIR/2008), New York, 2008. United Nations publication, Sales No. E.08. II.D.3; and Economic Commission for Latin America and the Caribbean (ECLAC), Foreign Direct Investment in Latin America and the Caribbean 2008 (LC/G.2406-P), Santiago, Chile, 2008.

their motivation, the more of them that set up in the South, the greater the demand for labour will be and the stronger the eventual upward pressure on local wages. This is what happened in Japan. The country started out with highly labour-intensive, low-paying industries, but labour became less and less abundant as the years passed and investment increased, and wages (and productivity) rose as a result, so that Japan now pays higher wages than the United States. The same thing happened in the Republic of Korea and Taiwan Province of China, and is happening now in China and India. In the long run, therefore, FDI makes labour less abundant and raises wages, but this effect is neither immediate nor automatic. It depends on national policies, and it needs to be supported by the power of unions. ${ }^{3}$

\footnotetext{
${ }^{3}$ This may be why most studies find that wages paid by transnational enterprises in the South are substantially higher than local wages. Either they pay better because they bring higher standards from their home countries, or they do so to increase productivity, allowing our unions to capture part of this rent if they negotiate well. See, once again, Micklethwait and Woolridge (2000) and Brown, Deardorff and Stern (2003).
} 
These effects are produced not only by FDI, of course, but by any kind of investment, be it local or foreign, and all investment is therefore to be encouraged. Since only a relatively small share of FDI goes to the South, however (a third of the total), and most of this is sited in relatively few countries (China and Brazil, among others), there is ample scope for attracting such investment to other countries. Furthermore, FDI usually brings better technology with it, and thus tends to create more productive and better-paid jobs. This is why it is important for the region's unions to encourage both greater investment in general and a larger flow of FDI to the South. More FDI widens the scope for countries of the South and their unions to raise potential productivity and wages, an option that will not exist if these countries receive little in the way of FDI, as has been the case with most of the economies of the South to date.

The third channel of globalization is the migration of labour, which may be potentially the fastest and most direct way of raising incomes and productivity in the world as labour moves from where it is abundant (the South) to where it is scarce (the North). As we shall shortly see, however, it is the channel that is least used and, indeed, least discussed. And when it is discussed, it is perhaps the one that arouses the strongest feelings in both the North and the South.

It is not that there is no migration, but that it is proceeding at a snail's pace. As expected (see table 5), migration takes place mainly from developing to developed countries. It can be seen from table 6, however, that annual migration (legal, that is), while large in absolute terms (2.6 million a year), is low compared to annual population growth: $3.2 \%$ of the world's annual population increase and just 3\% of the annual increase in the population of the South. To provide an example and a comparison, it is estimated that a third of the increase in population in Europe during the nineteenth century was absorbed by migration to the New World. ${ }^{4}$ A comparable figure would require a 10-fold increase in today's level of migration from South to North!

As already mentioned, feelings on the issue run high on both sides. Although today's migration represents only a small percentage of developing countries' population growth, the sharp slowdown of population growth in the North means that $54 \%$ of this is accounted for by migration from the South (which

\footnotetext{
${ }^{4}$ Estimate based on Maddison (2001).
}

actually supplies over $100 \%$ of population growth in Europe and Japan, with a much lower percentage only in the United States and Oceania). This is why many in the North resent these workers taking away their jobs and driving down their high wages, and why there is such strong nationalist pressure to halt migration, both legal and, obviously, illegal.

As for the South, it wounds people's pride that so many of their compatriots have to leave their home country in search of a better life abroad. There is also concern in the countries of the South about a "brain drain" depriving them of the resource they have invested most in and have most need of.

Against these legitimate concerns we must set the benefits of migration. First, it usually means a substantial improvement in the living standards of migrants themselves in terms not just of incomes but of health and learning as well. The less skilled the emigrant, the greater the benefit, for while wages in the North are higher than those in the South in all professions and occupations, the gap is particularly large for low-skilled workers, who earn something like subsistence wages in the South but are paid decently in the North by local standards and very handsomely indeed by those of the South. Although there are pay gaps for professionals, they are substantially less, particularly when adjusted for actual differences in the cost of living.

Second, there is a positive effect for those who do not migrate. For one thing, migration reduces competition for the few good jobs available locally. For another, emigrants usually send remittances to their families in the South. Remittances to the South last year are estimated at US\$ 328 billion, or 2.5 times the external assistance provided by the countries of the Organisation for Economic Co-operation and Development (OECD). ${ }^{5}$ For example, remittances by Indians abroad exceeded FDI in India that year! And remittances are not confined to money, there are also "remittances" of ideas. Indeed, there is evidence of a substantial transfer of knowledge in this way. Some of the success of the information technology production cluster in Bangalore, India, for example, is due to Indian engineers who formerly worked in Silicon Valley and used their knowledge to set up similar businesses in Bangalore. On a smaller scale, similar phenomena can be seen in the case of African and Central American emigrants returning to their

\footnotetext{
5 See "Migration and development: the aid workers who really help" in The Economist, 10 October 2009.
} 
TABLE 5

\section{Migration, 2000-2005}

\begin{tabular}{|c|c|c|c|c|c|c|}
\hline \multirow{2}{*}{$\begin{array}{l}\text { Recipient country } \\
\text { United States }\end{array}$} & \multirow{2}{*}{$\begin{array}{c}\begin{array}{c}\text { Immigrants } \\
\text { per year }\end{array} \\
1160000\end{array}$} & \multicolumn{5}{|c|}{$\begin{array}{l}\text { Main countries of origin } \\
\text { (percentages) }\end{array}$} \\
\hline & & Mexico & China & Philippines & India & Cuba \\
\hline & & 18 & 7 & 5 & 4 & 3 \\
\hline \multirow[t]{2}{*}{ Spain } & 405000 & Morocco & Ecuador & Romania & United Kingdom & Colombia \\
\hline & & 14 & 11 & 10 & 7 & 6 \\
\hline \multirow[t]{2}{*}{ Germany } & 220000 & Poland & Turkey & Romania & Hungary & Italy \\
\hline & & 18 & 7 & 4 & 4 & 2 \\
\hline \multirow[t]{2}{*}{ Canada } & 210000 & China & India & Philippines & Pakistan & United States \\
\hline & & 12 & 12 & 8 & 4 & 3 \\
\hline \multirow[t]{2}{*}{ United Kingdom } & 137000 & Australia & France & United States & New Zealand & India \\
\hline & & 9 & 8 & 7 & 6 & 5 \\
\hline World & 2600000 & & & & & \\
\hline
\end{tabular}

Source: United Nations, International Migration Report 2006: A Global Assessment (ESA/P/WP.209), New York, 2006. N.B.: 2000-2005 averages.

TABLE 6

Scale of migration, by development level

\begin{tabular}{lccc}
\hline & World & Developed countries & Developing countries \\
\hline Immigration (millions of people a year) & 2.6 & 2.6 & -2.6 \\
Population (millions of inhabitants) & 6500 & 1200 & 5 \\
Population growth (millions of people a year) & 82 & $0.4 \%$ & 77 \\
Percentage of population & $1.3 \%$ & $54 \%$ & $1.5 \%$ \\
Immigration (as percentage of population growth) & $3.2 \%$ & $-3 \%$ \\
\hline
\end{tabular}

Source: United Nations, International Migration Report 2006: A Global Assessment (ESA/P/WP.209), New York, 2006.

home countries with capital and ideas to make their projects work.

For reasons like the above, the latest Human Development Report of the United Nations concluded that migration yielded a net benefit both for those emigrating and for those remaining in their home countries, and that it was clearly beneficial too for the recipient countries themselves. ${ }^{6}$

Nonetheless, there are large barriers to migration, particularly for the low-skilled, who are precisely the people most likely to benefit from the opportunity to migrate. Migration continues to be seen as something

\footnotetext{
6 United Nations (2009).
}

each country may legitimately restrict at will. And by contrast with customs tariffs or barriers to capital inflows or outflows, not only is it unquestioned that countries have the right to restrict migration, but there is little awareness that they might have a duty to remove such barriers to migration. This is why the latest Human Development Report, which advocates reducing and liberalizing barriers to immigration for the low-skilled in particular, is so important. ${ }^{7}$ Hitherto,

7 See United Nations (2009). The Report advocates a six-pillared package of reforms including, among other things, liberalization and facilitation of immigration for the low-skilled, for both temporary and permanent jobs; guarantees for the basic rights of immigrants in destination countries; and reduction of the transaction costs involved in migration. 
there has been no international organization calling for steady reductions in the restrictions on immigration, as there are to encourage trade and capital flows. This is therefore a field that merits determined action by unions in the South, since emigration of low-skilled labour can significantly alleviate the negative pressure on labour markets in the South.

A fourth form taken on by globalization is the imitation, purchase and transfer of best practices and technologies. Over $80 \%$ of patents are generated in the developed countries, and much the same is presumably true of unpatented innovations. It is therefore reasonable to assume that the bulk of technology transfer will be from North to South. Furthermore, the enormous productivity gaps between the two suggest that transfer flows ought to be large.

Some of this transfer takes place through the purchase of equipment incorporating technological improvements. Indeed, almost half of all fixed capital investment is in equipment and machinery; expressed as a proportion of GDP, that means that some $10 \%$ of GNP consists of imported equipment incorporating modern technology. Another part of the technology flow consists in (smart) imitation and local adaptation of international best practices (the idea of shopping malls or mini-markets, or just-in-time production, for example, can be copied without having to pay anything). Lastly, another element is the payment of royalties for licences and franchises.

Given the huge productivity gaps and technological backwardness of developing countries, these could be expected to buy technology in large amounts. Indeed, as might be anticipated, successful emerging countries such as the Republic of Korea, Portugal and Spain spend 2.5 times as much on technology transfers (some $0.5 \%$ of GDP) as the developed countries themselves (see table 7). Conversely, and unexpectedly, the opposite is true of Latin America. It is striking that, other than in Argentina, royalty payments as a share of GDP in the Latin American countries run at only a fifth of their levels in successful emerging countries. Even more surprisingly, technology purchases in the region run at just half the rate seen among developed countries $(0.1 \%$ of GDP as against $0.2 \%$ of GDP in the developed countries).

In other words, technology transfer to Latin America falls well short of what it could be and ought to be for economies like those of the region, lagging as they do so far behind the technology frontier and international best practices. As a result of this slow transfer of technology, the huge gaps in productivity and thus incomes that separate Latin America from the developed economies have tended to persist.

Fifth, late-developing countries have one, and only one, great advantage. It is that once they have dealt with the institutional and endemic limitations of underdevelopment, they have the capacity to grow at much higher rates than the countries that historically were the first to develop. The later a country's development begins, the further behind the technology frontier it is, and thus the more quickly it can grow by bypassing whole stages of development and copying and adapting the modern technologies best suited to it. This is the phenomenon known as "catch-up" (see figure 3). This explains why Japan was able to grow so rapidly from the late nineteenth century; why subsequently, from 1950 onward, the "tigers" grew even faster than Japan during their miracle; and why continental China has been expanding at unprecedented rates since the 1980s, its per capita growth rate of over $7.5 \%$ far outstripping anything the "tigers" ever achieved. Nor can there be any doubt that much of the "Chilean miracle" from the mid-1980s to the present has been due to its success in finally capitalizing on this, the one great advantage of being a late-developing country.

TABLE 7

Technology transfer licensing payments (Percentages)

\begin{tabular}{lc}
\hline Country/region & Annual licensing payments/GDP \\
\hline Latin America & \\
$\quad$ Mexico & 0.12 \\
Brazil & 0.08 \\
Chile & 0.10 \\
Argentina & 0.34 \\
Developed countries & \\
Europe & 0.28 \\
Japan & 0.20 \\
Canada & 0.20 \\
Australia & 0.09 \\
Emerging countries & \\
Republic of Korea & \\
Portugal & 0.50 \\
Spain & 0.60 \\
\hline
\end{tabular}

Source: Roberto Álvarez, Gustavo Crespi and Joseph Ramos, "The impact of licenses on a 'late starter' LDC: Chile in the 1990s", World Development, vol. 30, No. 8, Amsterdam, Elsevier, August 2002.

GDP: Gross domestic product. 
FIGURE 3

\section{Catch-up: the great potential advantage of late development}

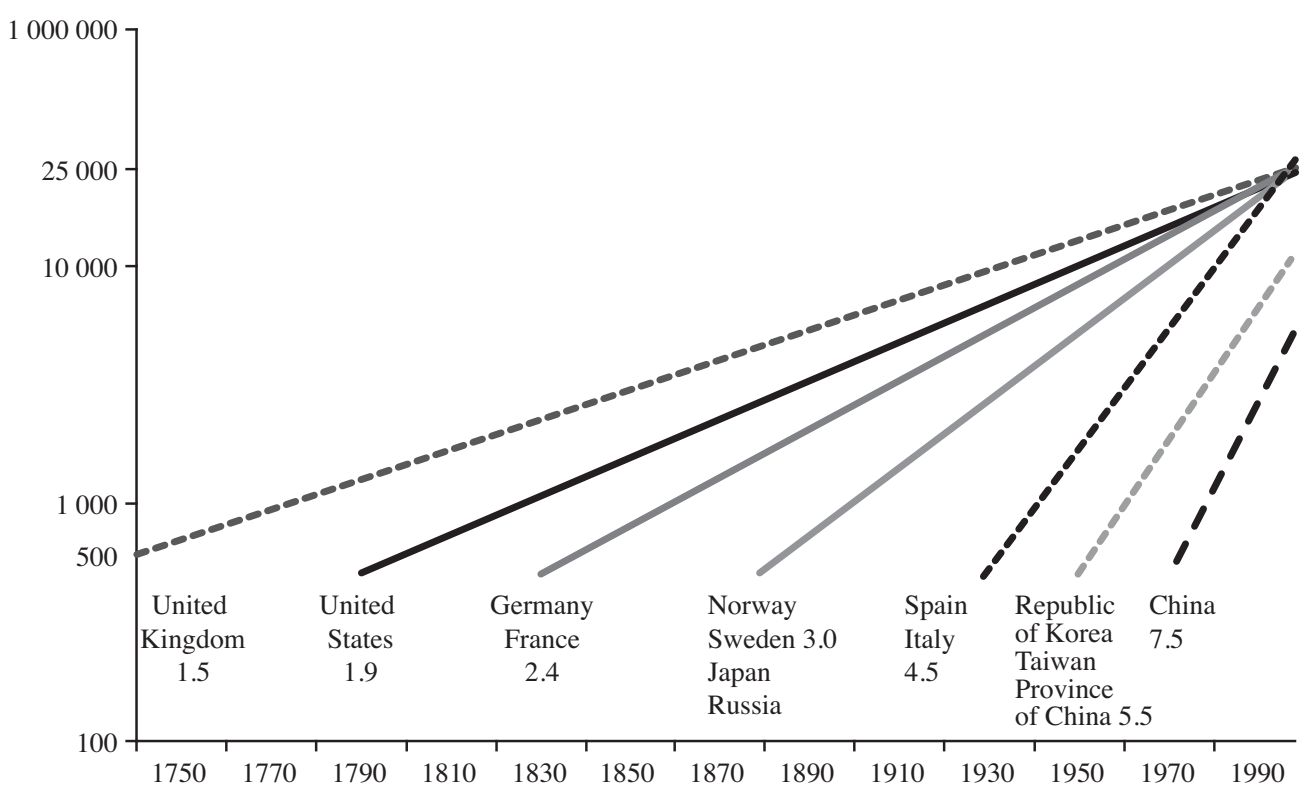

Source: prepared by the author on the basis of Angus Maddison, The World Economy: A Millennial Perspective, Paris, Organisation for Economic Co-operation and Development (OECD), 2001, and author's information.

N.B.: The vertical axis measures per capita income, the horizontal axis years. The values below each of the countries indicate the annual rate of growth of per capita income in that country since its take-off.

Far from closing the technology and best practice gaps with the developed countries, however, productivity in Latin America, with the exception of Chile, has grown by less than that of the developed countries from 1980 to the present, so that the technology frontier has receded even further. ${ }^{8}$ This shows how much remains to be done in this field. It must be stressed once again that the possibility of securing decent jobs with decent wages requires productivity levels much higher than are currently the norm in the region's countries.

To attain these goals, the transfer of technology and best practices is an even more vital factor than trade, FDI and migration. ${ }^{9}$ This is the potential flow

\footnotetext{
8 See Castaldi and others (2009).

9 None of this is an argument against domestic research and innovation. The region currently invests little in research and development (R\&D): some $0.6 \%$ of GDP. Although technology transfer will undoubtedly be more important for Latin America than endogenous technological innovation in its current stage of development, some R\&D is needed just to be able to assimilate and adapt international technologies and best practices. Again, while most firms in the region are a long way from the technology frontier, some of them, including many natural resource exporters, are close to it, which means that they need to carry out substantial $R \& D$ investment if they wish to maintain their elevated rents.
}

that is there to be exploited in future by developing countries, and Latin America in particular. Indeed, for all his criticisms of globalization, Stiglitz emphasizes that it is this capability - that of identifying the most suitable technologies and practices for their countries and then adapting, assimilating and disseminating them - that ultimately explains the Japanese miracle, that of the "Asian tigers" and those of China and India today. It was this ability to imitate, adapt and assimilate technologies, far more than orthodox neoliberal policies, that he considers to account for their success. ${ }^{10}$

In summary, a review of globalization, like the one conducted so far, yields one great conclusion: globalization has not advanced quickly or slowly so

\footnotetext{
10 See Stiglitz (2003). Indeed, that author argues that there have been large departures from neoliberal doctrine: some countries have engaged in far-reaching State intervention based on large local enterprises (Republic of Korea); some (Taiwan Province of China) have favoured the development of medium-sized firms for military reasons; others have opted to attract multinationals (Singapore); others again have developed with a large State sector (China) in both the productive economy and, particularly, the financial system. Until recently, furthermore, all these approaches were combined with substantial tariff barriers.
} 
much as asymmetrically, since goods, capital, labour and technology have flowed at very different speeds.

i) So far, globalization has advanced most quickly where trade in goods is concerned, with Latin American exports rising to $25 \%$ of GDP. This is followed by FDI flows, which have come to account for $18 \%$ of all annual investment. Conversely, globalization has progressed much less in the areas of technology transfer and migration. Unfortunately, these are probably the very two factors that could most quickly and directly improve living standards in the region, with its abundant labour and low-productivity jobs.

ii) There is much more globalization between developed countries (North-North) than between developed and developing ones (North-South). Two thirds of FDI and three quarters of exports are between developed countries.

iii) Only migration takes place mainly between South and North, but it is advancing at rates that are not high in absolute terms (3\% of developing countries' population growth) and are much lower than the rates seen in nineteenth-century Europe.

\section{III}

\section{Trade unions}

\section{Their role}

Unions play a multiplicity of roles both within firms and in society as a whole. The focus in what follows will be on their function in collective negotiations with firms. There are many, particularly among proponents of more orthodox economic theories, who see unions simply as actual or incipient monopolies that raise wages for their members at the expense of jobs for those excluded. It is undeniable that a union, especially if it is strong, can produce this effect. But this is an exaggeratedly restrictive view of the typical or average union.

Thus, more sophisticated labour market theories see unions as institutions that improve, or can improve, the workings of the market. First, there are markets with imperfect competition, in which the firm concerned generates rents in excess of normal profitability. In these cases, it will be in the interests of the firm to keep the whole of the rent deriving from its market power, paying its workers on the basis of their opportunity cost (their value to other firms)
Consequently (see table 8), the developing world, with $81 \%$ of the world's population, produces just $26 \%$ of global GDP. This is because it accounts for only $19 \%$ of all patents each year and $29 \%$ of exports, while it is home to just $14 \%$ of the world's largest enterprises. The developing world weighs only in terms of population and the percentage of raw materials it exports $(37 \%$ of the world total).

TABLE 8

International asymmetries

(Developing-country shares, percentages)

\begin{tabular}{lll}
\hline 1. & Population & 81 \\
2. & GDP & 26 \\
3. & Percentage of 500 largest firms & 14 \\
4. & Patents & 19 \\
5. & Exports & 36 \\
6. & Raw material exports & 37 \\
\hline
\end{tabular}

Source: United Nations Conference on Trade and Development (UNCTAD), Development and Globalization: Facts and Figures, Geneva, 2006.

GDP: Gross domestic product. and not their actual productivity. In these situations, a critical task for the union will be to press for some of these rents to be transferred to its members. In these cases, the distribution of this rent will depend on the negotiating power of the parties and, within wide margins, will have no distorting effect on the allocation of resources. ${ }^{11}$

Secondly, even in fully competitive markets, there is often another type of rent that gives rise to a margin of "legitimate indeterminacy" where wages are concerned. This can be understood better if we begin with the most orthodox analysis of the workings of competitive markets. According to this, the pressure characterizing relationships in competitive markets is known as "exit". In other words, if someone does not like a product, they stop buying it and choose another. This "exit" sends the producer a message that he must improve the quality or price of the

\footnotetext{
${ }^{11}$ See Benavente, Dobbelaere and Mairesse (2009) for an interesting analysis of how rents are distributed in accordance with the bargaining power of workers in France, Belgium and Chile.
} 
product, or both, or otherwise perish. In the labour market, similarly, anyone dissatisfied with the working conditions of his firm can leave, and his "exit" will put pressure on the firm to adapt its operations to the demands of its workforce.

Exit is undeniably an important form of pressure, but it is not the only one. Particularly in markets with more or less skilled labour, where relationships are deeper and longer-term and where exit costs are high, there is also a place for pressure exerted by means of "voice". Unions provide this voice. ${ }^{12}$ Firms are sensitive to such pressure because they know that the effort put in by their staff largely depends on how fairly they believe they are being treated.

There is, then, an area of "legitimate indeterminacy" where wages are concerned. Although the market sets limits or ranges to how much is to be paid for a certain type of labour, this is rarely an exact amount other than in highly exceptional markets. There is normally a range of $5 \%$ to $10 \%$ around a certain value. This range depends on all the factors that can make the productivity of a worker or group of workers higher in one particular firm than in the general run of firms. Among other factors, for example, their productivity may be greater because they have acquired specific knowledge about the workings of their firm, or because they have forged a good team spirit with colleagues, making the productivity of each greater than it would be in another firm. There is thus a range of "legitimate indeterminacy" corresponding to the greater productivity workers may have in their firm by comparison with the general run of firms. This greater productivity generates a rent that may be appropriated by the worker or by the firm or divided between the two, without greatly affecting the level of employment. ${ }^{13}$ This rent is a subject for negotiation, and "voice" is the most efficient way of going about this. Thus, one of the key roles of a union is to express the "voice" of workers as a group.

Third, apart from collective bargaining as such, in medium-sized or large firms there will always be

\footnotetext{
12 Originated by Hirschman (1970), this theory has been very usefully applied to the world of unions by Freeman and Medoff (1984), among others. See also Pencavel (2008) and Dussaillant (2008).

13 Much more may be demanded, in which case there will be a distorting effect, with wages being raised not just at the expense of the firm's rents but at the cost of a lower level of employment. What is meant here by the area of "legitimate" indeterminacy is that which does not distort the allocation of resources but remains within the bounds set by the greater specific productivity of workers in that firm by comparison with the rest.
}

situations that are not covered by employment contracts and require interpretation or new agreements. Employers are obviously attracted by an arrangement in which they take decisions or impose their will without argument. This lends itself to arbitrary behaviour, however, and can ultimately damage labour relations, thereby affecting morale and thence productivity. This is why unions have the function of representing worker interests and legitimizing agreements. Given that labour productivity and performance are known to depend not only on workers' capacities, but on how fairly they feel they are being treated, this legitimizing function of the union benefits both the firm and its workers.

These roles of distributing rents, negotiating ranges of "legitimate indeterminacy", checking arbitrary behaviour and facilitating unanticipated new agreements are vital and positive roles of unions, greatly valued by workers and, in large firms particularly, valued too by the employers themselves. This is why modern theories of labour relations do not regard these as essentially adversarial, with one side necessarily gaining at the other's expense (a "zero sum game"), but treat them as potentially beneficial all round if well conducted. Negotiated working conditions are viewed as fair and thus call forth a greater effort from employees than the same working conditions when they are imposed and employees feel their views have not been considered, since their productivity depends on their motivation, and their motivation depends in part on whether they feel their interests have been taken into account.

\section{The view of workers}

The above may seem theoretical, but it is amply borne out by experience. In a survey recently carried out by the Equity Commission of the Government of Chile, the following results were obtained: ${ }^{14}$

i. Between $75 \%$ and $80 \%$ of workers consider a union to be important or very important for securing fair treatment, more of a say in their company's decisions, better wages and more stable employment.

ii. $49 \%$ consider that unions have a positive effect on productivity; only $5 \%$ believe their effect to be negative.

\footnotetext{
14 See Consejo Asesor Presidencial, Trabajo y Equidad (2008). This government-appointed commission was composed of "wise men" from a wide range of political, academic, business and union backgrounds, and many of its conclusions were unanimous.
} 
iii, $81 \%$ think it would be desirable to improve workers' collective bargaining capacity.

iv. While $68 \%$ feel trust or a great deal of trust in the promises of their company's management, a large percentage $(27 \%)$ have little or no trust in management, whence the need for an organization like a union to give greater credibility to whatever is agreed upon.

v. By contrast with the ultra-orthodox position that labour relations are a "zero sum game", $66 \%$ of workers believe that relations between their union and their firm are cooperative or very cooperative, with only a fraction $(20 \%)$ regarding them as adversarial or very adversarial.

The same survey also shows that the closer the source of authority is, the better labour relations tend to be, and obviously that the more remote it is, the worse they tend to be. This alone would explain the greater need for a union in large firms, where employment conditions are not set by the immediate supervisor but tend to be more impersonal and distant. For example, whereas $82 \%$ of respondents say they have a good or very good relationship with their immediate supervisor, this positive appreciation drops to $65 \%$ in the case of company management and $46 \%$ in the case of the company's owners.

\section{The importance of unions}

Unions can be important when they contain a large percentage of the workforce, as in the Nordic countries, and when union contracts are extended to the non- unionized workforce, as in France where, despite declining union membership, the coverage of such contracts has increased.

Nonetheless, it should be observed (see table 9) that there has been a fall in both the percentage of workers in unions (down 33\%) and the coverage of union-negotiated contracts (down by a lesser but still substantial 22\%) in most of the OECD countries over the past 25 years. A similar downward trend can be seen in Latin America (see table 10). ${ }^{15}$

This decline in the percentage of unionized workers is due to many factors, among which mention may be made of the following: ${ }^{16}$ greater international competition due to globalization, and thus a decline in the monopolistic rents available to be shared out between firms and workers, making unionization less attractive; technological changes that have facilitated decentralization and outsourcing of jobs, reducing typical company size (smaller firms are usually less unionized); the growing weight of the (far less unionized) "tertiary" sector in economy activity and the declining share of manufacturing employment (highly unionized for the most part); the growing importance of professional and whitecollar occupations in firms, as these are typically less unionized; the rise in female employment, which is normally less unionized both because of the type of work women do and because their participation in the workforce is more intermittent; anti-union policies and

\footnotetext{
15 See Dussaillant (2008).

${ }^{16}$ See Pencavel (2008).
}

TABLE 9

Unionization and coverage of union-negotiated contracts

(Selected OECD countries, percentages)

\begin{tabular}{|c|c|c|c|c|}
\hline \multirow[t]{2}{*}{ Country } & \multicolumn{3}{|c|}{ Percentage of workers unionized } & \multirow{2}{*}{$\begin{array}{l}\text { Percentage change in coverage of union- } \\
\text { negotiated contracts (1980-2000) }\end{array}$} \\
\hline & 1980 & 2000 & Percentage change & \\
\hline United Kingdom & 51 & 31 & -39 & -57 \\
\hline Japan & 31 & 22 & -29 & -40 \\
\hline United States & 22 & 13 & -41 & -46 \\
\hline Germany & 35 & 25 & -29 & -15 \\
\hline France & 18 & 10 & -44 & 13 \\
\hline Sweden & 80 & 79 & -1 & 13 \\
\hline Australia & 48 & 25 & -48 & 0 \\
\hline Italy & 50 & 35 & -30 & 0 \\
\hline OECD & 32 & 21 & -33 & -22 \\
\hline
\end{tabular}

Source: Organisation for Economic Co-operation and Development (OECD), OECD Employment Outlook, Paris, 2004. 
TABLE 10

Unionization in Latin America

(Percentages)

\begin{tabular}{lccc}
\hline Country & Start year & End year & Percentage change \\
\hline Argentina & $68(1986)$ & $50(1995)$ & -26 \\
Colombia & $25(1985)$ & $18(1995)$ & -28 \\
Costa Rica & $30(1985)$ & $18(1995)$ & -40 \\
Chile & $16(1990)$ & $15(2006)$ & -7 \\
El Salvador & $10(1985)$ & $11(1995)$ & 10 \\
Guatemala & $10(1985)$ & $8(1994)$ & -20 \\
Mexico & $42(1991)$ & $20(1997)$ & -52 \\
Panama & $21(1991)$ & $20(1995)$ & -5 \\
Uruguay & $30(1988)$ & $21(1993)$ & -30 \\
Venezuela (Bol. Rep. of) & $29(1988)$ & $18(1993)$ & -38 \\
\hline
\end{tabular}

Source: Francisca Dussaillant, "Sindicatos y negociación colectiva", Documento de trabajo, No. 374, Santiago, Chile, Centro de Estudios Públicos, 2008.

practices; and the disrepute into which some unions have fallen because of their lack of transparency and internal democracy. In fact, it is only in public-sector activities that unionization is on the increase.

\section{The effects of unionization on employment and income distribution}

As mentioned earlier, one of the most frequent criticisms of unions from an orthodox perspective is that they raise their members' wages at the expense of employment. Thus, by imposing a wage higher than is justified by worker productivity and market conditions (i.e., outside the upper end of the range of legitimate indeterminacy), unions force firms to reduce recruitment, with the result that unemployment or informality rises. Although a thorough test of this hypothesis is beyond the scope of the present study, some light can be shed on it by examining whether, as this hypothesis would have it: (i) countries with a higher degree of unionization have higher unemployment (the sample used in this study are the OECD countries in 2000 or thereabouts) and (ii) the decline of unionization in the last 25 years (from the 1980 s to the early 2000s) has been accompanied by a drop in unemployment.

Figure 4 examines the relationship between the percentage of the workforce which is unionized and unemployment in OECD countries around 2000. Contrary to the conventional orthodox hypothesis, the feared positive relationship between unemployment and unionization is not observed. ${ }^{17}$ To take this a step further, figure 5 shows this relationship over time (from 1980 to the early 2000s), i.e., it examines whether, as the conventional hypothesis suggests, unemployment fell by more in countries where unionization retreated most, such as the United States, the United Kingdom and Japan, and whether it increased less in countries where union membership fell by less or even rose, such as Finland, Iceland, Belgium and Sweden. Once again, no statistically significant relationship is observed between increasing (decreasing) unemployment rates and rising (falling) union membership rates.

This conclusion is borne out by more detailed OECD (2004) studies using multiple control variables, which show that between 1970 and 2000 there was no robust relationship between union membership and unemployment rates. ${ }^{18}$ The ambiguity or lack of robustness of the relationship between unemployment

\footnotetext{
17 The finding is similar if we compare union membership and unemployment around 1980. The lack of significance cannot therefore be put down to the period chosen.

18 While, as conventional theory suggests, OECD (2004) finds that higher unemployment is associated with greater coverage of collective bargaining for some periods and some regressions between 1970 and 2000, the relationship between higher unemployment and a higher unionization rate is not significant for any regression or period. And although, as conventional theory suggests, higher collective bargaining coverage correlates with less employment of older people, greater unionization is associated with higher employment in general and higher female employment in particular, contrary to what the orthodox theory would predict. Given such inconsistent, ambiguous and unstable results, OECD (2004) concludes that there is no robust correlation between unionization and unemployment.
} 
FIGURE 4

\section{Relationship between union membership and employment}

(OECD, 2000)

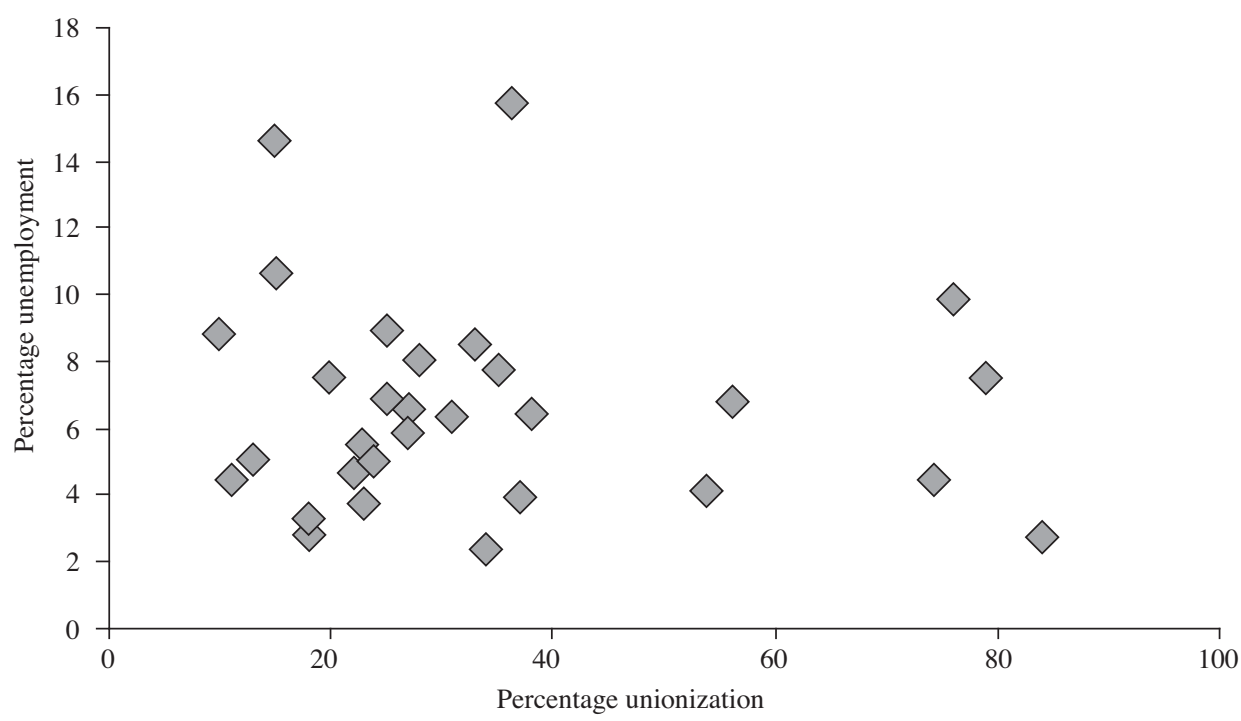

Source: based on data from the Organisation for Economic Co-operation and Development (OECD), 2000.

N.B.: There is no statistically significant relationship between the unemployment rate and the unionization rate.

FIGURE 5

\section{Effect of falling union membership on unemployment} $(1980 s-2000 s)$

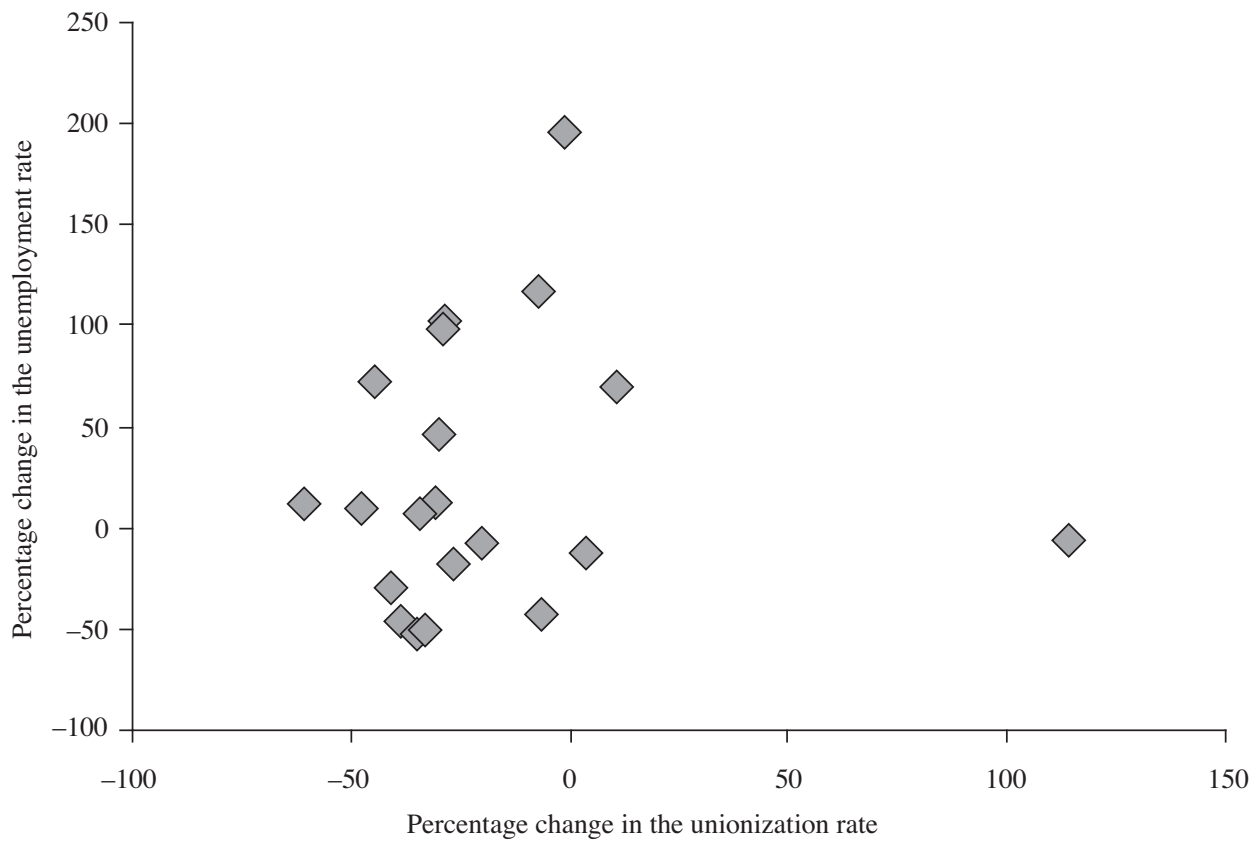

Source: based on data from the Organisation for Economic Co-operation and Development (OECD).

N.B.: There is no statistically significant relationship between percentage changes in unemployment rates and percentage changes in unionization rates. 
and unionization suggests that the interaction between these variables is influenced by a variety of institutional arrangements that can heighten or actually reverse the conventional relationship expected. Conversely, this ambiguity or lack of robustness is consistent with our hypothesis that unions mainly raise wages within the range of "legitimate indeterminacy" but do not generally abuse it, so that a higher degree of unionization is not usually "distortionary", i.e., does not have a significant effect on employment levels.

In complete contrast to the above hypothesis, proponents of unionization argue that, by raising wages within the range of "legitimate indeterminacy", particularly for the most vulnerable, unions reduce wage inequality or at least help to keep it within acceptable limits. If this claim is true: (i) wage inequality ought to be less in highly unionized countries (such as the Nordic ones) and greater in countries with a low degree of unionization (such as France, Spain and the United States); and (ii) wage inequality ought to have increased in countries where union membership has fallen by more (Japan, the United Kingdom and the United States) or by much more than in countries where unionization declined only modestly or actually increased.
Figure 6 relates union membership to wage inequality around the year 2000. The results of the regression are consistent with this hypothesis: the higher the degree of unionization, the lower the degree of inequality. ${ }^{19}$ And this time the relationship is statistically significant. For example, a country with a unionization rate of $20 \%$ will have an inequality ratio of some 3.4 between the highest and lowest wage deciles, while a country with a unionization rate of $40 \%$ will have an inequality ratio between deciles of 3 to 1 .

This hypothesis is confirmed when trends in union membership and inequality are observed over time. The larger the fall in the unionization rate between 1980 and 2000, the greater the percentage increase in wage inequality (see figure 7), and once again the relationship is statistically significant. A reduction of $33 \%$ in the degree of unionization (from $32 \%$ to $21 \%$ ), as seen on average in the OECD between 1980 and 2000, increases wage inequality by some $9 \%$. In other words, if inequality between the first and tenth deciles was

${ }^{19}$ For a better comparison, inequality between the highest and lowest wage deciles is measured for men in full-time employment.

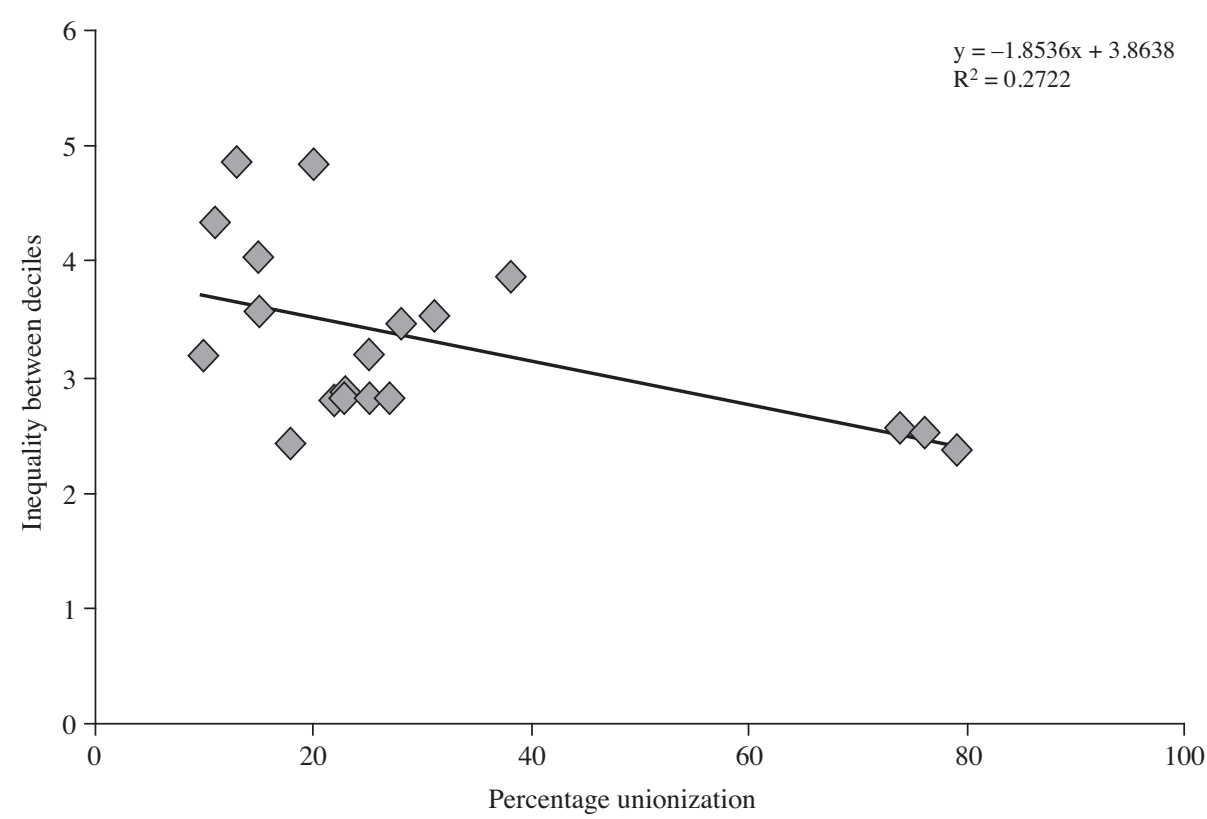

Source: based on data from the Organisation for Economic Co-operation and Development (OECD).

N.B.: Relationship significant at a $95 \%$ confidence level. 
3 to 1 , then $33 \%$ lower unionization would increase the inequality between deciles to almost 3.3 to 1 . By contrast with the previous hypothesis, furthermore, OECD (2004) finds that this relationship between greater unionization and lesser wage inequality is robust in more complex analyses. ${ }^{20}$ It thus concludes that the higher the rate of unionization, collective bargaining coverage or both, the lower the degree of

20 The discussion about the effect of unions on employment and income distribution is further-reaching than the sample given above. Among other things, there is a huge literature on the types of unions (centralized or decentralized) and their repercussions. Again, see OECD (2004). wage inequality, and that this finding "accords with a considerable number of earlier studies (Blau and Kahn, 1999; OECD, 1997a) and can be considered to be quite well established".

On the basis of this information, we can conclude that a heavy burden of proof rests with the orthodox position, which sees unions as essentially negative institutions. The fact is that, besides the theoretical arguments in favour of unionization ("voice" and not just "exit"), the available evidence for its repercussions on employment (non-significant) and equity (significant) suggests that, even if these were their only effects, unions are an institution that ought to be encouraged rather than the reverse.

FIGURE 7

The effect of falling union membership on inequality

(OECD, 1980s-2000s)

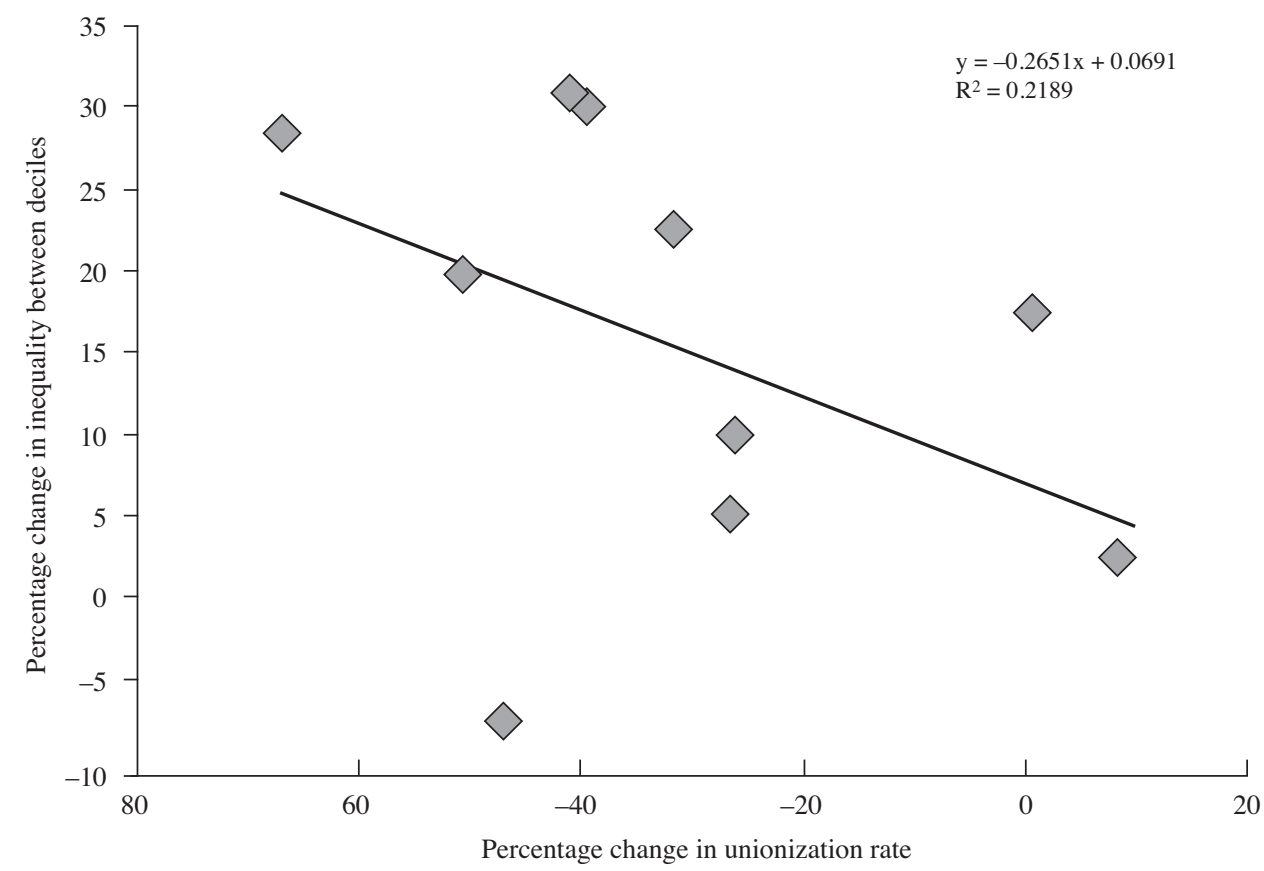

Source: based on data from the Organisation for Economic Co-operation and Development (OECD).

N.B.: Relationship significant at a $95 \%$ confidence level. 


\section{IV}

\section{The impact of globalization on unions and its political implications}

\section{The impact of globalization on unions}

Before the 1980s, the dominant strategy in Latin America was import substitution industrialization (ISI) entailing strict tariff protection of domestic markets. In countries such as Mexico and Brazil, with their large markets, this strategy produced vigorous and indeed unprecedented economic growth averaging over $6 \%$ a year between 1945 and 1980. The strategy was less successful in economies with smaller domestic markets and thus low productivity levels, as the local market was often inadequate for even a single firm to achieve a minimum efficient scale of production. A case in point were Argentinean and Chilean automobile firms which, because of their small national markets, operated with a great deal of spare capacity and had to charge well over the international price for vehicles. Thus it was that the economic performance of countries such as Argentina, Chile and Uruguay during the ISI period was mediocre, with per capita growth rates of some $1.5 \%$. This strategy was discontinued, of course, in the 1980s, when the external debt crisis led to a strategic shift in the region from a domestic market-centred model (ISI) to a development model oriented towards the penetration of external markets.

These two strategies had and continue to have important and different implications for the development of the union movement in the region's countries. By securing the domestic market for the local producer, the ISI strategy created a monopolistic rent for local firms at the expense of consumers. This rent was naturally coveted by unions, since it derived not from any special effort or greater productivity on the part of the firm, but from the protection provided by the political authority. It was a clear case of a zero sum game between capital and labour, and it naturally gave rise to essentially adversarial relationships.

When the region's economies were opened up, external competition drastically reduced or even eliminated monopolistic rents, in some cases causing firms to shut down and in general reducing profits greatly. As monopolistic rents disappeared, the fate of employers and their workers came to depend on the success of the firm as a whole in the face of competition from abroad. Profits, if any, were no longer spurious, the gift of the authorities, but real, deriving from the efforts of the whole firm to improve productivity and compete. Since higher productivity is the result of cooperation between capital and labour, labour relations between the parties become more cooperative in these circumstances, while the main "conflict" becomes that of competing abroad. However, as noted earlier, cooperation between the parties generates a specific rent for the firm that gives rise to a range of "legitimate wage indeterminacy" requiring negotiation between the parties to determine its allocation.

\section{The political implications for unions}

What fields of negotiation have been becoming more important for unions in this new globalized environment? We shall distinguish between fields that have gained in prominence outside of firms (first at the international level and then at the national level) and those that have done so within firms.

\section{a) Outside of firms, at the international level}

Whereas the ISI strategy centred on the nation and the firm, globalization has given rise to issues that transcend these and bring the international level to prominence. A particular issue for international discussion is everything connected with the asymmetries in the current globalization process. Globalization must mean the greatest flow of all factors of production, not just goods and capital but technology and labour too.

Hitherto, it seems to have been an unquestioned axiom of globalization that goods and capital should flow as freely as possible, whereas the same is not said of migratory flows, for example. This subject needs to be considered, not as it so far has been as an exclusively national prerogative (of the country receiving migrants) but as a natural counterpart of the increased flow of all the factors of production. Although the 2009 Human Development Report restates this case on behalf of the international community, it should be 
reinforced by unions in the South. The fact is that improving worker incomes in the region's countries must mean reducing today's relative abundance of low-skilled labour. Can there be any faster way of reducing this abundance than promoting greater migration of low-skilled labour to the developed countries (where a great deal of low-skilled labour is needed in tasks for which demand is constantly increasing, such as caring for the sick and elderly)? Just as a relatively free flow of labour was important for the development of Europe in the nineteenth century, and just as freedom of worker movement is important now for the European Union and the new economies that have joined it from its east, so a greater flow of migrants to the North could be an important element in the improvement of working conditions for the masses in the South. Emigration is no substitute for better national development strategies, but it can very usefully supplement them, and it should therefore be firmly supported by unions in the South, backed too out of solidarity by unions in the North.

This does not mean the South making greater capital inflows conditional on the acceptance of a greater outflow of migration (since it could be even worse for developing countries to have less FDI as well as few opportunities for migration). But it must be said yet again that globalization entails the greatest possible flow of all factors of production between countries; ultimately, indeed, the unrestricted flow of both labour and capital. Thus the aim must be a greater rate of migration of labour (conditional at most on the culture of the recipient country being upheld): not just any labour, but lower-skilled labour in particular, in sharp contrast with the present situation where recipient countries accept or even attract skilled and professional labour but shun or reject unskilled labour. And once again, they do this as though migration were a subject of exclusively national concern, unlike the trade in goods and capital flows, where international interests are considered to take precedence over merely national ones. It will obviously not be easy to turn the present situation around, which is why it is essential to create an awareness that the free flow of labour from South to North is the natural counterpart of the free flow of capital in the other direction. And here unions in both the North and the South have an important role to play.

The corollary of this defence of unrestricted migration is the strengthening of employment regulations in both the origin and destination countries. Recipient countries that have still not ratified international conventions protecting migrant workers need to do so. In any event, and as recommended by the 2009 Human Development Report, countries ought to ensure that migrants have full employment rights and equal pay for equal work, benefit from decent, safe working conditions, can organize collectively and enjoy full rights to education and learning of the destination country's language for their children. Furthermore, both origin and destination countries ought to work together to facilitate recognition of educational and occupational skills acquired in the home country.

\section{b) Outside of firms, at the national level}

First of all, in a globalized world it is going to be increasingly important to uphold basic employment rights, not only in the letter (conventions) but in practice. This is important in itself and also instrumentally if the countries of the region desire access to international markets, since it is going to become more and more unacceptable to import from countries that do not uphold standards or that routinely flout them. An important role for unions will be to strive to ensure that national standards incorporate the international principles set forth in the different conventions and recommendations of the International Labour Organization (ILO).

Of course, these rules cannot be identical in detail to those of developed countries, but they need to embody the same principles, adjusted for differences in development level. They should include similar clauses, with a view to convergence as development gaps narrow. Although the precise details must vary by development level, all countries need to introduce strict limits if not an outright ban on child labour, place limits on the normal working day, consider establishing a minimum wage or income, implement protection for unions and promote collective bargaining, and set minimum occupational safety and hygiene standards, among other measures.

Second, in a globalized world whose economies are increasingly intertwined and thus subject to the vagaries of the international economy, it will be necessary to design policies to defend workers from recessions caused by external shocks. Sound macroeconomic policy is obviously the first line of defence for employment. This is why it is essential for unions to press consistently for countercyclical policies with the greatest number of "built-in stabilizers".

Among the most important of the stabilizers that should be advocated are fiscal policies that vary 
automatically with the business cycle, i.e., that entail saving during times of prosperity so that deficits can be run in downturns. The Chilean policy of structural balance is exemplary in this respect. It means that the public budget is designed so that spending is calculated not from the fiscal revenues of the moment, but from the revenue that would be obtained if the economy continued to grow at its trend rate and the price of copper (a key export) were at its long-term average. This means that the exchequer saves and generates a surplus during upturns when the copper price is high, allowing it to spend more than it takes in during downturns when the economy is growing below potential and the copper price is below its longterm value. The outcome of this policy is that public spending is neutral to the cycle, unlike that of many countries where it reinforces the cycle. It is because of this policy that the current international crisis has had less of a recessionary impact and produced fewer after-effects in Chile than the Asian crisis.

A third recommendation that should be pressed for is the design of policies to help minimize lay-offs when recession cannot be avoided. In recessionary situations, when sales and thus output fall, employment needs to be cut back. What unions are advised to propose is that, in such situations, the authorities encourage firms to reduce the working day, by $10 \%$ say, rather than dismissing $10 \%$ of their staff. ${ }^{21}$ Harsh though this may be, anyone can adjust to earning $10 \%$ less, but no-one can adjust to earning $100 \%$ less, which is what unemployment means. Consequently, in situations declared recessionary by the competent authority, it is socially preferable for firms to scale back their labour requirements through across-the-board reductions in the working day rather than through dismissals. Interestingly, a number of OECD countries have adopted measures of this nature during the recent international crisis, so that although Germany, for example, has suffered a more severe recession than the United States, unemployment has risen by much less there.

\footnotetext{
${ }^{21}$ This encouragement can simply take the form of making provision for firms to be allowed to cut working hours (and remuneration in proportion) unilaterally in situations declared recessionary by a competent authority, without this constituting a breach of the employment contract, and providing that workers who consider this unfair and resign will receive the compensation due for dismissal. The assumption must be that in such situations, when many firms are shedding staff, the vast majority of workers will prefer a $10 \%$ cut in working hours to a $10 \%$ cut in staff. This could be induced more energetically if governments also provided a partial subsidy (of $50 \%$, for example) for the loss of hours, so that only half this reduction was reflected in the worker's pay packet.
}

Advocating legislation to authorize cuts in working hours instead of dismissals is, then, another important challenge for unions at the national level.

Fourth, unions in the South need to press for the introduction of unemployment insurance. This is not just a luxury for developed countries but a necessity for any country that is subject to economic crises in a globalized world. Logically, the sums involved will depend on the country's development level, the level of formal employment and the practicalities of administration. However, unemployment insurance is a critical instrument for unions because, for one thing, it sustains the incomes (cushions the losses) of those who most need it, the unemployed. For another, by stabilizing the unemployed's income it lessens the downward pressure on the earnings of those in work.

Fifth, productive employment depends critically on workforce education and training. This is why the key demand of unions is that all young people entering the workforce must have a proper trade; they should not start work without one, as now happens with most of those who enter the labour market after graduating from or dropping out of secondary education. Furthermore, continuous productivity improvements can only be achieved with a workforce that is continually upgrading its skills. This means it is important to ensure that all workers are guaranteed opportunities for regular training throughout their working lives if they so desire.

This means advocating, first, that all young people who drop out of or graduate from secondary education but do not go into higher education receive a credit entitling them to a good-quality higher technical education (usually lasting two years). Otherwise young people without a proper trade will be condemned to low-productivity work throughout their active lives. Ensuring they have the opportunity to acquire a proper trade means they will be able to earn a wage that places them in the country's middle class (reducing the worst inequalities characteristic of developing countries) and gives them upward mobility during their career. Such a measure is affordable for most developing countries, at least those in the middle-income bracket, and returns are so high that it will pay for itself many times over. ${ }^{22}$

\footnotetext{
22 The cost of a good higher-level technical education is estimated at US\$ 4,000 (US\$ 2,000 a year over two years) in a country at an intermediate stage of development, such as Chile. Assuming two thirds of young people do not go into higher education,
} 
Another measure to be advocated is an entitlement for all workers to follow training courses for $1 \%$ of their working lives (which would means five months' training over a working life of 45 years instead of the one or two months the average workers currently receives in the region), with a view to accelerating growth in workers' productivity and thus their wages over the course of their careers. The only condition would be for training to be provided in an institution of accredited quality and preferably in areas and types of work deemed of high priority by the authorities.

Sixth, minimum wage policies (whose cost is absorbed by firms) should be reconsidered to see whether it is not preferable for unions to press for a guaranteed minimum income (at least part of whose cost would be absorbed by the exchequer). In closed economies, the cost of a higher minimum wage could be passed on to consumers without any extra outlay by the firm, so that the effect of a higher minimum wage on unemployment was small. In open economies, on the other hand, a higher minimum wage cannot be passed on to consumers, meaning that firms have to absorb any increases in this minimum that are not offset by productivity gains, so that higher pay considered socially necessary could have potentially negative consequences for employment.

A minimum income higher than the minimum wage can be introduced without negative consequences for employment if the difference between the wage earned and the minimum income deemed to be the acceptable baseline is absorbed by the exchequer in the form of a subsidy for low earners, rather than by the firm. In this case, the worker will receive what is deemed to be the acceptable baseline income but the cost to the firm will not rise, so that there is no incentive to avoid employing people. Of course, this entails a fiscal cost that will be absorbed by the whole of society, or by all firms. Since it is independent of the level of employment, however, it will not discourage this in the way a minimum wage can do.

\section{c) Within firms}

Negotiating the most appropriate employment conditions within the so-called range of "legitimate indeterminacy" for wage levels has traditionally

this would imply a cost of some $0.5 \%$ of GDP for a country with per capita GDP of US\$10,000 at purchasing power parity (PPP) in the event that funding was by non-reimbursable credits, i.e., outright grants. The cost would obviously be much less if credits were partially reimbursable on the basis of how well the recipient scored at graduation (which would encourage everyone to strive harder to learn their trade). been a function of unions and will continue to be in the future. As was explained earlier, this range is the $5 \%$ or $10 \%$ by which the specific productivity of workers in a particular firm may exceed (or fall short of) the individual productivity of those workers in other firms.

Besides this function, globalization has meant that in more open economies it is becoming increasingly necessary and desirable to seek forms of negotiation that allow firms to compete abroad and collaborate internally. One of the most interesting proposals here is for the negotiation of "profit-sharing wages". 23 Current pay systems tend to operate on the basis of a set wage for a fixed length of time. In recessions, consequently, firms have an incentive to dismiss workers, as the obligation to pay the fixed wages agreed upon prevents them from lowering their costs. When a large portion of workers' earnings are variable, on the other hand (an agreed percentage of sales, or of the value of output, or the value added of the firm, or profits), companies will be more willing to cut prices in recessions because the variable wage component will also fall to some extent, and they will consequently tend to maintain output and employment. During upturns, conversely, the variable component of workers' earnings automatically rises and they share in the firm's prosperity.

Accordingly, profit-sharing wages have the attractive effects of minimizing loss of output and employment in hard times and improving income distribution (relative to what it would otherwise have been) during upturns. This is not just theoretical. ${ }^{24}$ Profit-sharing wages are widely paid in Japan, with a variable component of some $25 \%$ of total earnings. As a result, Japanese unemployment never rose above $5.5 \%$ even in the recession and long stagnation of the late 1990s.

A further virtue of profit-sharing wages is that, by linking the earnings of workers as a group more closely to the performance of the firm, they induce greater effort and higher productivity. This form of remuneration, indeed, promotes greater collaboration within the firm and is a better defence against the vagaries of the international economy. A recent

\footnotetext{
23 This policy, described below, was proposed and popularized by Weitzman (1984)

${ }^{24}$ See Weitzman and Kruse (1989). Marinakis (1999) has an interesting analysis of the problems involved in operating different profit-sharing systems in Latin America. He concludes that when these systems are the result of collective bargaining rather than legally imposed, they are an important instrument for improving both labour relations and competitiveness.
} 
publication concludes that "a system of remuneration of this type [profit-sharing], when properly thought out, properly explained and implemented honestly and transparently, is unquestionably one of the most powerful management tools available to any SME" (Berg, 2007).

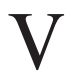

\section{Conclusion}

Looking beyond temporary ups and downs that may cause globalization to retreat (the recent international crisis, for example) or to advance more quickly, it seems clear that it is here to stay. Furthermore, the long-term trend is likely to be towards yet further integration of the world's economies. It is important, however, that current asymmetries be reduced.

While international trade flows have increased the most so far, it is important for the unions of the South that capital flows and technology transfers between countries should accelerate, as these have an essential role to play in raising the low productivity levels of the South, and thus in providing opportunities for decently paid work. As far as the supply of labour is concerned, today's low levels of migration show globalization at its weakest. As the 2009 Human Development Report suggests, significantly increasing such flows, particularly of unskilled labour, would have a decisive effect in alleviating the relative abundance of labour in the South which, with a handful of exceptions (mining and the public sector), considerably constrains the bargaining power of unions there.
While there has been some reluctance to adopt it, ${ }^{25}$ there has been a trend towards the introduction of remuneration of this kind. Consequently, it is reasonable to propose that unions should press for future increases in their members' earnings to take this form rather than that of higher fixed wages alone.
Globalization is not just affecting unions, however, but is providing them with new opportunities for action, some of which have been highlighted in this article. Unions have a long history and will continue to play an important role in the future regardless of the speed of globalization, particularly if they focus on roles like those indicated here, which are coming increasingly to the fore with globalization.

(Original: Spanish)
Álvarez, Roberto, Gustavo Crespi and Joseph Ramos (2002), "The impact of licenses on a 'late starter' LDC: Chile in the 1990s", World Development, vol. 30, No. 8, Amsterdam, Elsevier, August.

Benavente, José Miguel, Sabien Dobbelaere and Jacques Mairesse (2009), "Interaction between product market and labour market power: evidence from France, Belgium and Chile", Applied Economics Letters, vol. 16, No. 6, London, Routledge, April.

Berg, Hubert (2007), Salarios participativos: una herramienta para el compromiso, Santiago, Chile, International Labour Organization (ILO).

Bhagwati, Jagdish (2004), In Defense of Globalization, New York, Oxford University Press.
Blau, Francine and Lawrence Kahn (1999), "Institutions and laws in the labor market", Handbook of Labor Economics, O. Ashenfelter and D. Card (eds.), vol. 3, Amsterdam, North Holland.

Brown, Drusilla, Alan Deardorff and Robert Stern (2003), "The effects of multinational production on wages and working conditions in developing countries", NBER Working Paper, No. 9669, Cambridge, Massachusetts, National Bureau of Economic Research.

Castaldi, Carolina and others (2009), "Technological learning, policy regimes, and growth: the long term patterns and some specificities of a globalized economy", Industrial Policy and Development, Mario Cimoli, Giovanni Dosi and Joseph Stiglitz, New York, Oxford University Press. 
Consejo Asesor Presidencial, Trabajo y Equidad (2008), Encuesta: percepciones sobre relaciones laborales y equidad, Santiago, Chile, August.

Dusaillant, Francisca (2008), "Sindicatos y negociación colectiva", Documento de trabajo, No. 374, Santiago, Chile, Centre for Public Studies.

ECLAC (Economic Commission for Latin America and the Caribbean) (2008), Foreign Direct Investment in Latin America and the Caribbean 2008 (LC/G.2406-P), Santiago, Chile. United Nations publication, Sales No. E.09.II.G.24.

Freeman, Richard and James Medoff (1984), What Do Unions Do, New York, Basic Books.

Gray, John (1998), False Dawn: The Delusions of Global Capitalism, New York, New Press.

Hirschman, Albert (1970), Exit, Voice and Loyalty, Cambridge, Harvard University Press.

Maddison, Angus (2001), The World Economy: A Millennial Perspective, Paris, Organisation for Economic Co-operation and Development (OECD).

Marinakis, Andrés (1999), "Worker participation in company profits or operating results in Latin America", CEPAL Review, No. 69 (LC/G.2067-P), Santiago, Chile, December.

Micklethwait, John and Adrian Wooldridge (2000), A Future Perfect: The Hidden Promise of Globalization, New York, Times Books.

OECD (Organisation for Economic Co-operation and Development) (2004), "Wage-setting institutions and outcomes", OECD Employment Outlook, Paris.

(1997), OECD Employment Outlook, Paris.
Pencavel, John (2008), "Una mirada internacional al sindicalismo", Estudios públicos, No. 110, Santiago, Chile, Centre for Public Studies.

Stiglitz, Joseph (2003), Globalization and its Discontents, New York, Norton.

The Economist (2009), "Migration and development: the aid workers who really help", 10 October.

UNCTAD (United Nations Conference on Trade and Development) (2008), World Investment Report, 2008 (UNCTAD/WIR/2008), New York, 2008. United Nations publication, Sales No. E.08.II.D.3.

(2006), Development and Globalization: Facts and Figures, Geneva.

United Nations (2009), Human Development Report. Overcoming Barriers: Human Mobility and Development, New York. (2006), International Migration Report 2006: A Global Assessment (ESA/P/WP.209), New York.

Visser, Jelle (2006), "Union membership statistics in 24 countries", Monthly Labor Review, vol. 129, No. 1, Washington, D.C., Bureau of Labor Statistics, January.

Weitzman, Martin (1984), The Share Economy, Cambridge, Harvard University Press.

Weitzman, Martin and Douglas Kruse (1989), "Profit sharing and productivity", Paying for Productivity, Alan Blinder (ed.), Washington, D.C., The Brookings Institution.

World Bank (2009), World Development Report 2009, Washington, D.C. WTO (World Trade Organization) (2008), World Tariff Profiles 2008, Geneva. 